\title{
Pengaruh Komite Audit dan Managerial Entrenchment terhadap Agresivitas Pajak serta Implikasinya terhadap Kinerja Keuangan Perusahaan
}

\author{
Lalu Andika Noviawan' 1 \\ Fakultas Ekonomi dan Bisnis \\ Universitas Mataram, Indonesia \\ Email: laluandika23@gmail.com
}

\author{
Lilik Handajani ${ }^{2}$ \\ Fakultas Ekonomi dan Bisnis \\ Universitas Mataram, Indonesia
}

\section{Nyoman Nugraha Ardana Putra ${ }^{3}$ \\ Fakultas Ekonomi dan Bisnis \\ Universitas Mataram, Indonesia}

\begin{abstract}
ABSTRAK
Penelitian ini bertujuan untuk menganalisis hubungan antara komite audit dan managerial entrenchment terhadap agresivitas pajak serta implikasinya terhadap kinerja keuangan perusahaan. Sejumlah 71 perusahaan manufaktur di Bursa Efek Indonesia selama periode 2015-2017 menjadi sampel penelitian. Hasil analisis data menggunakan Partial Least Square menunjukkan bahwa managerial entrenchment dan agresivitas pajak memiliki pengaruh signifikan negatif terhadap kinerja keuangan. Managerial entrenchment mengurangi permintaan perusahaan untuk monitoring terhadap manajer yang mangakibatkan penurunan kinerja keuangan. Sementara itu, agresivitas pajak dapat menutupi tindakan rent extraction manajer yang berimbas pada menurunnya kinerja keuangan.
\end{abstract}

Kata Kunci: Agresivitas Pajak; Komite Audit; Managerial Entrenchment; dan Kinerja Keuangan.

The Effect of Audit Committee and Managerial Entrenchment on Tax Aggressiveness and Their Impact for Corporate Financial Performance

\section{ABSTRACT}

This study aims to analyze the relationship between the audit committee and managerial entrenchment on tax aggressiveness and its implications for the company's financial performance. A total of 71 manufacturing companies on the Indonesian Stock Exchange during the 2015-2017 periode were research samples. The results of data analysis using Partial Least Square show that managerial entrenchment and tax aggressiveness have a significant negative effect on financial performance. Managerial entrenchment reduces the company's demand for monitoring of managers which results in a decrease in financial performance. Meanwhile, tax aggressiveness can cover managers' rent extraction actions that impact on declining financial performance.

Keywords: Audit Committee; Managerial Entrenchment; Tax Aggressiveness; Financial Performance.

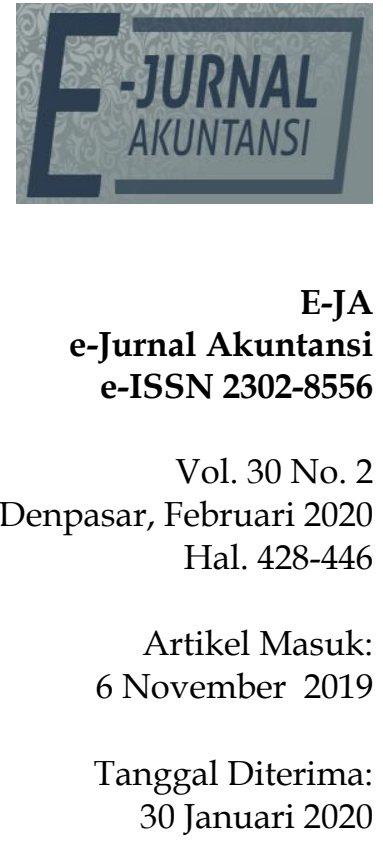




\section{PENDAHULUAN}

Tindakan manajer untuk mengurangi beban pajak atau sering disebut agresivitas pajak memiliki daya tarik besar bagi shareholders. Pembayaran pajak yang lebih rendah dari semestinya membuat shareholders terlebih perusahaan dapat menikmati porsi kas lebih besar. Tentunya penghematan pajak ini menjadi keuntungan, mengingat tujuan perusahaan untuk ekspansi usaha dan tetap survive di tengah persaingan bisnis. Bagian terbaik dari aktivitas ini adalah sulit terdeteksi otoritas pajak karena skema yang digunakan tidak melanggar hukum dengan memanfaatkan loophole undang-undang yang berlaku.

Salah satu kasus penghindaran pajak yang menyita perhatian adalah kasus yang melibatkan Asian Agri Group. Tahun 2014, majelis hakim Mahkamah Agung memutuskan Asian Agri Group bersalah atas kasus penghindaran pajak dan harus melunasi pajak terhutang sebesar Rp 1,2 triliun beserta denda dua kali pajak terhutang yakni sebesar Rp 2,5 triliun(www.detik.com, 2014). Modus yang dilakukan perusahaan adalah dengan menggelembungkan biaya operasional perusahaan, membuat kerugian fiktif saat melakukan lindung nilai alias hedging, serta melakukan transfer pricing. Semua tindakan tersebut menyebabkan laba Asian Agri menurun sehingga tagihan pajak juga ikut menurun (www.ortax.org, 2007).

Berbagai kasus penghindaran pajak yang terjadi dapat dijelaskan oleh positive accounting theory dalam political cost hypothesis. Hipotesis ini mengargumentasikan bahwa perusahaan yang sensitif terhadap aspek politik memiliki biaya politik yang besar. Manajer pada perusahaan seperti itu akan memilih suatu metode akuntansi yang dapat mengurangi laba agar tekanan politik terhadap perusahaan berkurang (Watts \& Zimmerman, 1986). Tarif pajak progresif otomatis membuat perusahaan dengan tingkat laba tinggi membayar pajak tinggi. Beban pajak yang tinggi membuat perusahaan berusaha untuk menguranginya melalui agresivitas pajak (Chen, Chen, \& Shevlin, 2010).

Tindakan agresivitas pajak dapat menimbulkan kerugian bagi perusahaan seperti adanya kemungkinan dikenakan sanksi oleh fiskus pajak (Desai \& Dharmapala, 2006)(Chen et al., 2010) serta turunnya harga saham perusahaan (Hanlon \& Slemrod, 2009). Selain itu, perusahaan berisiko mengeluarkan biaya besar seperti pembayaran untuk ahli pajak, denda reputasi, dan denda kepada otoritas pajak (Midiastuty, Suranta, \& Ramdhan, 2017) (Dyreng, Hanlon, \& Maydew, 2018). Agar terhindar dari kerugian tersebut, maka diperlukan mekanisme corporate governance terutama untuk mengawasi tindakan manajer melalui peran dewan komisaris. Sebagai upaya mencapai efektivitas tugasnya, dewan komisaris dapat membentuk komite audit untuk memperkuat fungsi pengawasan atas proses pelaporan keuangan, pengawasan manajemen risiko dan kontrol, serta implementasi corporate governance. Melalui peran tersebut, komite audit dapat memperkuat mekanisme pengawasan sehingga berpotensi meminimalisasi tindakan agresivitas pajak.

Agency theory menjelaskan bahwa terjadi conflict of interest antara principal (pemilik) dengan agent (manajer). Manajer sebagai pengelola perusahaan dapat membuat keputusan yang mengungtungkannya, namun merugikan pemilik. Maka, ada alasan kuat bahwa manajer tidak selalu bertindak sesuai kepentingan pemilik (Jensen \& Meckling, 1976). Saat manajer tidak memberikan value bagi 
perusahaan, maka kemungkinan takeover akan mengancam posisi mereka. Jika penyesuaian insentif tidak meningkatkan kinerja manajer dan dewan menyatakan top manajernya tidak kompeten, maka dewan tidak punya banyak pilihan selain memberhentikan mereka (Walsh \& Seward, 1990).

Sebagai upaya mangamankan posisinya, manajer dapat melakukan initiative entrenchment (Walsh \& Seward, 1990) melalui agresivitas pajak yang dapat memberikan value bagi perusahaan dan shareholders. Initiative entrenchment oleh manajer atau managerial entrenchment merupakan strategi yang digunakan oleh manajer untuk mempertahankan posisinya dalam perusahaan ketika menghadapi tekanan dari shareholders dan pengendalian internal dengan cara mengimplementasikan praktik yang mampu mengelola hubungan dengan stakeholder perusahaan (Surroca \& Tribo, 2008) dalam (Handajani, Subroto, Sutrisno, \& Saraswati., 2014). Tindakan agresivitas pajak dapat menghemat pajak dalam jumlah besar (Chen et al., 2010) sehingga porsi kas yang dinikmati perusahaan dan shareholders menjadi lebih besar. Skema agresivitas pajak dapat menjadi strategi manajer untuk memberikan value bagi perusahaan guna menghindari takeover.

Keuntungan berupa pengematan pajak menjadi alasan shareholders mendukung tindakan agresivitas pajak. Sisi negatif dari tindakan ini dapat menutupi rent extraction yang dilakukan manajer (Desai \& Dharmapala, 2006) (Chen et al., 2010). Rent extraction merupakan aktivitas tidak memberi value maksimal kepada shareholders seperti manipulasi penyusunan laporan keuangan, mengambil aset perusahaan untuk kepentingan pribadi, dan transaksi dengan pihak yang memiliki hubungan istimewa (Chen et al., 2010). Tentunya berbagai tindakan rent extraction ini dapat merugikan perusahaan dan shareholders. Selain itu, agresivitas pajak dapat mengurangi transparansi laporan keuangan (Balakrishnan, Blouin, \& Guay, 2011), hasil analisis datanya menunjukkan agresivitas pajak berdampak pada kesalahan forecast (ramalan) perusahaan, peningkatan adverse selection, dan menurunkan kualitas akrual perusahaan.

Informasi yang terkandung dalam laporan keuangan dengan transparansi rendah dapat dikatakan kurang relevan karena tidak mencerminkan kondisi perusahaan sebenarnya dan dapat mempengaruhi kinerja perusahaan. (Edogbanya \& Kamardin, 2006) dalam penelitiannya memberikan bukti bahwa transparansi keuangan berpengaruh signifikan positif terhadap kinerja. Transparansi keuangan yang tinggi membuat kinerja perusahaan meningkat, sebaliknya rendahnya transparansi keuangan berimbas pada penurunan kinerja perusahaan. Tindakan agresivitas pajak dapat menurunkan transparansi laporan keuangan sehingga berdampak pada penurunan kinerja perusahaan. Tujuan penelitian ini adalah untuk menganalisis pengaruh komite audit dan managerial entrenchment terhadap agresivitas pajak serta implikasinya terhadap kinerja keuangan perusahaan.

Positive Accounting Theory dalam Political Cost Hypothesis mengargumentasikan bahwa perusahaan yang sensitif terhadap aspek politik memiliki biaya politik yang besar. Suatu metode akuntansi tertentu akan dipilih manajer untuk mengurangi laba agar tekanan politik perusahaan berkurang (Watts \& Zimmerman, 1986). Perusahaan dengan catatan laba tinggi akan dikenakan pajak yang juga tinggi akibat tarif pajak progresif. Pajak umumnya 
dinilai sebagai biaya paling besar bagi perusahaan (Gaaya, Lakhal, \& Lakhal, 2017). Pajak mereferesentasikan biaya yang signifikan bagi perusahaan dan mereduksi arus kas yang tersedia bagi perusahaan dan shareholders, hal ini menjadi pemicu bagi perusahaan untuk mengurangi pajak melalui tindakan agresivitas pajak (Chen et al., 2010).

Agresivitas pajak memunculkan manfaat yaitu penghematan pajak dalam jumlah besar (Chen et al., 2010), disisi lain merugikan perusahaan seperti kemungkinan diaudit dan dikenakan sanksi oleh otoritas pajak (Desai \& Dharmapala, 2006) (Chen et al., 2010) (Midiastuty et al., 2017)(Dyreng et al., 2018), turunnya harga saham (Hanlon \& Slemrod, 2009), serta biaya besar untuk pembayaran ahli pajak dan denda reputasi (Midiastuty et al., 2017). Kerugian tersebut dapat dihindari melalui mekanisme corporate governance, terutama pengawasan terhadap tindakan manajer oleh dewan komisaris. Dewan komisaris sebagai alat corporate governance dalam pengawasan dan pengesahan atas keputusan perusahaan untuk mengangkat, memberhentikan, pemberian kompensasi top manajer (Fama dan Jensen, 1983) dalam (Lanis \& Richardson, 2011). Agar peran tersebut efektif, maka dewan komisaris dapat membentuk komite audit yang bertugas untuk memperkuat fungsi pengawasan atas proses pelaporan keuangan, pengawasan manajemen risiko dan kontrol, serta implementasi corporate governance. Melalui peran tersebut, komite audit dapat memperkuat mekanisme pengawasan yang dapat meminimalisasi tindakan agresivitas pajak.

Penelitian yang dilakukan oleh (Dewi \& Jati, 2014) (Midiastuty et al., 2017) (Pradana \& Ardiyanto, 2017) (Wulansari \& Dewi, 2017)(Utami \& Syafiqurrahman, 2017) (Zheng, Jiang, Zhao, Jiang, \& Wang, 2019) menemukan bahwa semakin banyak jumlah komite audit yang fungsinya sebagai suatu mekanisme pengawasan perusahaan, maka akan meningkatkan kualitas good corporate governance sehingga akan memperkecil praktik agresivitas pajak. Berdasarkan uraian diatas, hipotesis yang dibangun adalah:

$\mathrm{H}_{1}$ : Komite audit berpengaruh negatif terhadap agresivitas pajak.

Perspektif agency theory memberikan pemahaman bahwa terdapat kontrak antara principal dengan agent untuk melakukan sejumlah jasa sesuai kepentingan principal dengan pendelegasian sejumlah wewenang dalam membuat keputusan. Konflik terjadi ketika agent bertindak hanya untuk keuntungannya namun merugikan principal (Jensen \& Meckling, 1976). Kemungkinan takeover dapat mengancam posisi manajer self serving karena tidak memberikan value bagi perusahaan dan shareholder. Ketika penyesuaian insentif tidak menyediakan peningkatan kinerja manajer dan dewan menyatakan top manajernya tidak kompeten, maka dewan tidak punya banyak pilihan selain memberhentikan (dismiss) mereka (Walsh \& Seward, 1990).

Manajer yang memiliki kontrol atas perusahaan dan memiliki sejumlah kecil saham, bekerja untuk mengamankan posisinya meskipun mereka tidak lagi memiliki kompetensi dan kualifikasi menjalankan perusahaan (Shleifer \& Vishny, 1988). Manajer dapat melakukan income smoothing dan praktik manajemen laba lainnya sebagai jalan untuk mengamankan pekerjaan mereka (Fudenberg \& Tirole, 1995) (Surroca \& Tribo, 2008). Sebagai upaya untuk mangamankan posisinya, manajer dapat melakukan initiative entrenchment 
(Walsh \& Seward, 1990) melalui tindakan agresivitas pajak. Keuntungan terbesar dari agresivitas pajak adalah penghematan pajak perusahaan dalam jumlah besar (Chen et al., 2010) sehingga perusahaan dan stakeholders dapat menikmati porsi kas yang lebih besar. Manajer yang ingin menghindari takeover dapat melakukan agresivitas pajak dengan tujuan memberikan value kepada perusahaan dan shareholders. Ketika strategi entrenchment dijalankan maka manajer cenderung lebih banyak melakukan agresivitas pajak.

Fudenberg \& Tirole, (1995) menyimpulkan managerial entrenchment berpengaruh positif terhadap manajemen laba (income smoothing). Manajer akan terdorong untuk melakukan manajemen laba dengan harapan dapat memperpanjang masa kerja mereka diperusahaan. Manajer akan melakukan manajemen laba dengan dua cara. Pertama meningkatkan laba saat perusahaan dalam situasi buruk untuk memperpanjang masa kerja (tenur). Kedua, ketika perusahaan dalam situasi baik, fokus manajer berkurang oleh prospek jangka pendek dan kepemilikan informasi mengenai prospek perusahaan mendorong mereka untuk menyimpan laba sebagai cadangan untuk situasi buruk di masa depan.

$\mathrm{H}_{2}$ : Managerial entrenchment berpengaruh positif terhadap agresivitas pajak.

Agency theory menyatakan manajer sebagai agent memiliki kewenangan untuk membuat berbagai keputusan terkait perusahaan, tidak terkecuali yang bersifat self serving dan merugikan stakeholder lainnya (Jensen \& Meckling, 1976). Perilaku self serving ini akan semakin meningkat pada perusahaan yang memiliki mekanisme pengawasan dan pengendalian yang lemah. Dewan komisaris bersama dengan komisaris independen serta komite audit merupakan mekanisme corporate governance yang paling utama di dalam pelaksanaan monitoring manajer (Fama, 1980) dalam (Hapsoro, 2008). Tugas komite audit dalam upaya monitoring tersebut berkaitan dengan memastikan kewajaran laporan keuangan, pelaksanaan struktur pengendalian intern, pelaksanaan audit internal maupun eksternal (Komite Nasional Kebijakan Governance, 2006). Fungsi tersebut dapat membatasi perilaku oportunistik manajer sekaligus memperkuat corporate governance yang berimbas pada peningkatan kinerja keuangan.

Penelitian Hapsoro, (2008) dan Manik, (2011) menyimpulkan komite audit berpengaruh positif terhadap kinerja perusahaan. Komite audit sebagai salah satu mekanisme corporate governance mampu mengurangi praktek manipulasi dan kecurangan dengan menjunjung prinsip corporate governance. Ketika perusahaan berjalan dengan kualitas mekanisme corporate governance disertai fungsi pengawasan yang baik, maka peningkatan kinerja perusahaan dapat tercapai.

$\mathrm{H}_{3}$ : Komite audit berpengaruh positif terhadap kinerja keuangan.

Agency theory memberikan argumentasi bahwa manajer sebagai pengelola perusahaan sekaligus decision maker tidak selalu bertindak untuk kepentingan principal, bahkan dapat membuat keputusan yang mengungtungkannya namun merugikan principal maupun stakeholder lainnya (Jensen \& Meckling, 1976). CEO dengan masa kerja yang lama membuat permintaan pemilik untuk monitoring CEOnya berkurang. Hal ini bukan disebabkan keinginan pemilik untuk mengurangi monitoring, namun karena corporate governance yang lemah 
mengurangi kemungkinan pemecatan (dismissal) berdasarkan kinerja, hasilnya adalah masa kerja CEO yang lama (Dikolli, Mayew, \& Nanda, 2014). Imbas dari kondisi tersebut adalah penurunan kinerja keuangan perusahaan.

Dikolli et al., (2014) dalam penelitiannya menyatakan bahwa masa kerja (tenure) CEO yang lama mengurangi penilaian (pemecatan) CEO berdasarkan kinerja. Hal ini menyebabkan menurunnya kinerja perusahaan. Temuan ini diperkuat oleh Mohamed, Jarboui, Baccar, \& Bouri, (2015) yang menyimpulkan bahwa lamanya masa kerja CEO berpengaruh signifikan negatif terhadap nilai perusahaan. Tenur CEO yang lama menandakan lemahnya sensitifitas turnover berdasarkan kinerja, kondisi ini dapat mengakibatkan penurunan nilai perusahaan.

$\mathrm{H}_{4}$ : Managerial entrenchment berpengaruh negatif terhadap kinerja keuangan.

Agency theory mengargumentasikan manajer sebagai pengelola perusahaan dapat membuat keputusan yang menguntungkannya, namun disisi lain merugikan shareholders (Jensen \& Meckling, 1976). Salah satu tindakan manajer adalah agresivitas pajak yang bertujuan menghemat pajak perusahaan. Aktivitas ini menguntungkan bagi shareholders karena porsi kas yang dinikmati lebih besar, namun dapat menimbulkan rent extraction (Desai \& Dharmapala, 2006) (Chen et al., 2010). Rent extraction adalah tindakan manajer yang tidak memberi value maksimal kepada shareholder seperti manipulasi laporan keuangan, mengambil aset perusahaan untuk tujuan pribadi, dan transaksi dengan pihak yang memiliki hubungan istimewa (Chen et al., 2010) Jensen dan Meckling (1976) dalam (Blaylock, 2016) mendefinisikan rent extraction sebagai konsumsi manajer atas sumber daya perusahaan untuk kepentingan pribadi.

Balakrishnan et al., (2011) menyimpulkan kerugian dari agresivitas pajak adalah mengurangi transparansi keuangan. Hasil analisisnya menemukan bahwa agresivitas pajak berdampak pada kesalahan forecast (ramalan) perusahaan, peningkatan adverse selection, dan menurunkan kualitas akrual perusahaan. Transparannya laporan keuangan berimbas pada kinerja keuangan. (Edogbanya \& Kamardin, 2006) membuktikan transparansi keuangan berpengaruh signifikan positif terhadap kinerja perusahaan. Artinya, semakin transparan keuangan perusahaan, maka semakin baik kinerjanya. Sebaliknya, transparansi keuangan yang rendah akan menurunkan kinerja perusahaan. Tindakan agresivitas pajak akan menurunkan transparansi laporan keuangan sehingga akan berdampak pada penurunan kinerja keuangan.

Kartikaningdyah \& Putri, (2017) memperoleh bukti bahwa agresivitas pajak membuka peluang bagi manajer untuk melakukan tindakan oportunistik. Berbagai manipulasi dapat dilakukan manajer untuk memaksimalkan utilitasnya. Aktivitas ini akan mengurangi transparansi perusahaan serta berdampak negatif pada kinerja perusahaan. (Hanlon \& Slemrod, 2009) menyimpulkan bahwa agresivitas pajak berpengaruh negatif terhadap harga saham. Perusahaan yang melakukan tindakan agresivitas pajak akan dimaknai investor sebagai budaya perusahaan untuk melawan otoritas pajak dan keinginan insiders untuk mengambil keuntungan. Hal ini membuat investor menilai laporan keuangan tidak relevan sehingga memunculkan reaksi negatif yang dapat mengurangi harga saham perusahaan.

$\mathrm{H}_{5}$ : Agresivitas pajak berpengaruh negatif terhadap kinerja keuangan. 
Positive Accounting Theory menjelaskan bahwa perusahaan yang sensitif terhadap aspek politik memiliki biaya politik yang besar. Manajer pada perusahaan tersebut memiliki kecenderungan memilih metode akuntansi yang dapat mengurangi biaya politik perusahaan (Watts \& Zimmerman, 1986). Manajer yang berpotensi melakukan tindakan agresivitas pajak dapat dimininalisasi dengan implementasi good corporate governance. Komite audit merupakan salah satu aspek untuk memperkuat good corporate governance melalui fungsi pengawasan yang dilakukan. Ketika peran komite audit berjalan efektif, maka agresivitas pajak dapat dikurangi.

Salah satu dampak negatif agresivitas pajak adalah rent extraction yang dilakukan manajer seperti tindakan memanipulasi laporan keuangan, mengambil aset perusahaan untuk tujuan pribadi, dan transaksi dengan pihak yang memiliki hubungan istimewa (Chen et al., 2010). Tindakan ini tentu merugikan perusahaan yang berdampak pada penurunan kinerja keuangan. Ketika komite audit memperkuat corporate governance melalui pengawasan yang efektif maka tindakan agresivitas pajak yang merugikan perusahaan akan berkurang. Pos-pos kebocoran akibat agresivitas pajak tertutupi, hasilnya berdampak pada peningkatan kinerja keuangan perusahaan.

$\mathrm{H}_{6}$ : Komite audit berpengaruh positif terhadap kinerja keuangan melalui agresivitas pajak.

Argumentasi agency theory menyatakan manajer tidak selalu bertindak untuk kepentingan principal maupun stakeholder lainnya. Manajer dapat membuat keputusan oportunis yang hanya menguntungkan pribadinya (Jensen \& Meckling, 1976). Kondisi tersebut menimbulkan konflik antara manajer dengan principal, sehingga mekanisme dan kontrol perusahaan dapat melakukan take over terhadap manajer yang tidak memberikan value bagi perusahaan (Walsh \& Seward, 1990).

Agresivitas pajak merupakan salah satu cara bagi manajer untuk memberikan value bagi perusahaan. Manfaat terbesar agresivitas pajak adalah penghematan pajak perusahaan dalam jumlah besar (Chen et al., 2010) sehingga perusahaan dan stakeholders dapat menikmati porsi kas yang lebih besar. Kondisi ini disisi lain memunculkan kerugian, salah satunya adalah rendahnya transparansi keuangan perusahaan (Balakrishnan et al., 2011) yang berimbas pada menurunnya kinerja keuangan (Edogbanya \& Kamardin, 2006).

$\mathrm{H}_{7}$ : Managerial entrenchment berpengaruh negatif terhadap kinerja keuangan melalui agresivitas pajak.

\section{METODE PENELITIAN}

Penelitian ini merupakan penelitian kuantitatif yang menggunakan jenis penelitian kausalitas. Hubungan antar variabel dalam penelitian ini berbentuk hubungan kausal yakni hubungan yang bersifat sebab akibat, dalam hal ini ada variabel independen dan dependen (Sugiyono, 2012). Populasi dalam penelitian ini adalah seluruh perusahaan manufaktur yang terdaftar di Bursa Efek Indonesia tahun 2015-2017. Teknik pengambilan sampel menggunakan purposive sampling untuk memperoleh sampel yang representatif sesuai kriteria yang telah ditentukan. 
Tabel 1. Perhitungan Sampel

\begin{tabular}{lll}
\hline No. & Kriteria Pemilihan Sampel & Jumlah \\
\hline 1 & $\begin{array}{l}\text { Perusahaan manufaktur yang terdaftar di Bursa Efek Indonesia pada } \\
\text { tahun 2015 - 2017 }\end{array}$ & 142 \\
2 & $\begin{array}{l}\text { Perusahaan manufaktur yang delisting pada periode 2015-2017 } \\
\text { Perusahaan manufaktur yang tidak menerbitkan laporan tahunan }\end{array}$ & $(1)$ \\
& $\begin{array}{l}\text { lengkap selama periode 2015-2017 } \\
4\end{array}$ & $\begin{array}{l}\text { Perusahaan manufaktur dengan laba sebelum pajak negatif (rugi) } \\
\text { dan beban pajak positif }\end{array}$ \\
5 & $\begin{array}{l}\text { Perusahaan manufaktur yang menggunakan mata uang pelaporan } \\
\text { selain rupiah }\end{array}$ & $(17)$ \\
& $\begin{array}{l}\text { Perusahaan yang memenuhi kriteria sampel } \\
\text { Jumlah sampel (71 x 3 tahun) }\end{array}$ & 71 \\
\hline
\end{tabular}

Sumber: Data Penelitian, 2019

Seluruh data penelitian ini adalah data sekunder dari laporan tahunan perusahaan manufaktur yang terdaftar di Bursa Efek Indonesia tahun 2015-2017. Data diperoleh dari website resmi BEI www.idx.co.id dan website resmi masingmasing perusahaan yang menjadi sampel.

Komite audit merupakan komite yang dibentuk dewan komisaris yang bertugas untuk memastikan bahwa laporan keuangan disajikan secara wajar sesuai dengan prinsip akuntansi yang berlaku umum, struktur pengendalian internal perusahaan dilaksanakan dengan baik, pelaksanaan audit internal maupun eksternal dilaksanakan sesuai dengan standar audit yang berlaku, dan tindak lanjut temuan hasil audit dilaksanakan oleh manajemen (Komite Nasional Kebijakan Governance, 2006) (KNKG, 2006). Komite audit diukur dengan jumlah anggota komite audit pada suatu perusahaan (Wulansari \& Dewi, 2017).

Managerial entrenchment merupakan strategi yang digunakan oleh manajer untuk mempertahankan posisinya dalam perusahaan ketika menghadapi tekanan dari shareholders dan pengendalian internal dengan cara mengimplementasikan praktik yang mampu mengelola hubungan dengan stakeholder perusahaan (Surroca \& Tribo, 2008) dalam (Handajani et al., 2014). Managerial entrenchment dalam penelitian ini diukur dengan tenur manajerial. Tenur manajerial adalah lama waktu seseorang menjabat pada posisi pimpinan (Allen, 1981). Tenur manajerial diukur dengan jumlah tahun seseorang menjabat sebagai direktur utama (CEO) di suatu perusahaan (Allen, 1981).

Agresivitas pajak adalah usaha meringankan beban pajak dengan tidak melanggar undang-undang (Mardiasmo, 2011). Agresivitas pajak dalam penelitian ini diukur dengan effective tax rates. Pengukuran ini digunakan untuk mengetahui beban pajak perusahaan dan menunjukkan aktivitas penghindaran pajak melalui besarnya tarif pajak yang dibayarkan oleh perusahaan dibandingkan dengan statutory tax rate di Indonesia (Midiastuty et al., 2017). Nilai ETR berkisar antara 0 (nol) hingga 1 (satu), ETR yang semakin mendekati nol berarti tingkat agresivitas pajak yang tinggi, sebaliknya semakin mendekati satu berarti agresivitas pajak rendah. ETR dihitung dengan rumus (Chen et al., 2010).

Effective Tax Rates $=\frac{\text { Beban pajakpenghasilan }}{\text { Labasebelumpajak }}$ 
Kinerja keuangan yaitu hasil akhir dari kegiatan akuntansi (siklus akuntansi) yang mencerminkan kondisi keuangan dan hasil operasi perusahaan (bentuknya berupa laporan keuangan) (Arif dan Yanuar, 2009) dalam (Gantino, 2016). Kinerja keuangan dalam penelitian ini diukur dengan return on assets (ROA). Pengukuran kinerja dengan ROA menunjukkan kemampuan menghasilkan laba dari aktiva yang dimiliki (Sari, Astuti, Suseno, \& Rahmawati, 2017). ROA digunakan sebagai ukuran kinerja operasional perusahaan (Klapper dan love, 2002) dalam (Sudiyatno \& Puspitasari, 2010). ROA dihitung dengan rumus (Frank, Lynch, \& Rego, 2009):

Return on Assets $=\frac{\text { PreTax Income }}{\text { Total Assets }}$

Penelitian ini menggunakan alat analisis Partial Least Square (PLS) untuk menguji model. Persamaan model struktural (inner model) sebagai berikut:

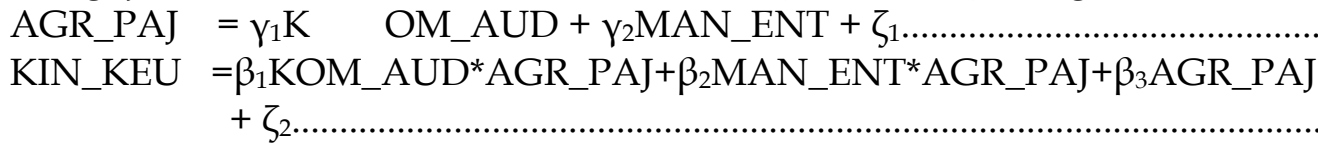

Keterangan:

KOM_AUD : Komite Audit,

dibentuk oleh indikator JUM_KA : Jumlah Komite Audit

MAN_ENT : Managerial Entrenchment

dibentuk oleh indikator TEN_MAN : Tenur Manajerial

AGR_PAJ : Agresivitas Pajak

dibentuk oleh indikator ETR : Effective Tax Rates

KIN_KEU : Kinerja Keuangan

dibentuk oleh indikator ROA : Return on Assets

$Y$ (gama) : koefisien pengaruh variabel eksogen terhadap variabel endogen

$\beta$ (beta) : koefisien pengaruh variabel endogen terhadap variabel endogen

$\zeta$ (zeta) : : galat model

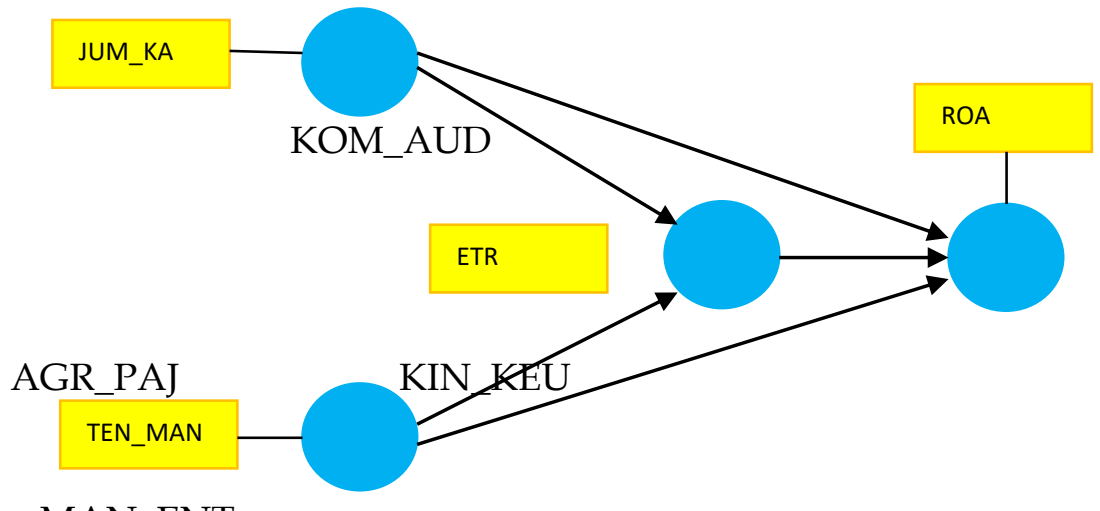

MAN_ENT

Sumber: Data Penelitian, 2019

\section{Gambar 1. Path Diagram}

\section{HASIL DAN PEMBAHASAN}

Hasil pengujian Partial Least Square (PLS) yang dilakukan pada model penelitian menunjukkan nilai koefisien determinasi $\left(R^{2}\right)$ sebesar $7,1 \%$. 
Tabel 2. Nilai Koefisien Determinasi $\left(\mathbf{R}^{2}\right)$

\begin{tabular}{ll}
\hline Konstruk & Nilai R \\
\hline Kinerja Keuangan & 0,071 \\
\hline Sumber: Data Penelitian, 2019 &
\end{tabular}

Hasil ini menjelaskan bahwa besarnya konstruk kinerja keuangan yang dapat dijelaskan oleh konstruk komite audit, managerial entrenchment, dan agresivitas pajak adalah 7,1\% sementara sisanya 92,9\% dijelaskan oleh konstruk lain yang tidak masuk dalam model penelitian ini.

Perubahan nilai koefiesien determinasi $\left(\mathrm{R}^{2}\right)$ ketika konstruk eksogen tertentu dihilangkan dari model dapat digunakan untuk mengevaluasi apakah konstruk tersebut memiliki dampak substantif pada konstruk endogen (Hair, Hult, Ringle, \& Sarstedt, 2014). Pedoman untuk menilai F² menurut Cohen (1988) dalam (Hair et al., 2014) yaitu 0,02 (kecil), 0,15 (menengah), dan 0,35 (besar). Nilai $\mathrm{F}^{2}$ setiap variabel penelitian ini disajikan pada Tabel 3. berikut:

Tabel 3. Nilai Effect Size ( $\left.\mathbf{F}^{2}\right)$

\begin{tabular}{lll}
\hline Hubungan Variabel & Nilai F 2 & Kebaikan Model \\
\hline KOM_AUD -> AGR_PAJ & 0,002 & Kecil \\
MAN_ENT -> AGR_PAJ & 0,006 & Kecil \\
KOM_AUD -> KIN_KEU & 0,003 & Kecil \\
MAN_ENT -> KIN_KEU & 0,04 & Kecil \\
AGR_PAJ -> KIN_KEU & 0,031 & Kecil \\
\hline
\end{tabular}

Sumber: Data Penelitian, 2019

Berdasarkan Tabel 3 diketahui bahwa effect size seluruh hubungan antar variabel masuk dalam kategori kecil. Nilai effect size tertinggi pada model penelitian ini adalah hubungan antara managerial entrenchment dengan kinerja keuangan sebesar 0,040. Sementara itu, nilai effect size terendah adalah hubungan variabel komite audit terhadap agresivitas pajak sebesar 0,002.

Hasil pengujian PLS yang dilakukan pada model penelitian menunjukkan bahwa H1, H2, H3, H6, dan $\mathrm{H} 7$ ditolak. Hasil berbeda ditunjukkan oleh H4 dan $\mathrm{H} 5$ yang diterima, karena nilai t-statistiknya lebih besar dari 1,96 ( $p$ value lebih kecil dari 0,05). Tabel 4 menunjukkan hasil analisis path coefficient

Tabel 4. Path Coefficients

\begin{tabular}{llllll}
\hline & $\begin{array}{l}\text { Original } \\
\text { Sample } \\
(\mathrm{O})\end{array}$ & $\begin{array}{l}\text { Sample } \\
\text { Mean } \\
(\mathrm{M})\end{array}$ & $\begin{array}{l}\text { Standard } \\
\text { Deviation } \\
(\text { STDEV) }\end{array}$ & $\begin{array}{l}\text { T Statistics } \\
(\mid \mathrm{O} / \text { STDEV } \mid)\end{array}$ & $\begin{array}{l}\text { P } \\
\text { Value } \\
\text { s }\end{array}$ \\
\hline KOM_AUD -> AGR_PAJ & $-0,042$ & $-0,049$ & 0,027 & 1,598 & 0,111 \\
MAN_ENT -> AGR_PAJ & 0,077 & 0,077 & 0,059 & 1,307 & 0,192 \\
KOM_AUD -> KIN_KEU & $-0,054$ & $-0,055$ & 0,037 & 1,447 & 0,148 \\
MAN_ENT -> KIN_KEU & $-0,195$ & $-0,199$ & 0,051 & 3,835 & 0,000 \\
AGR_PAJ -> KIN_KEU & $-0,170$ & $-0,197$ & 0,05 & 3,403 & 0,001 \\
KOM_AUD -> AGR_PAJ- & 0,007 & 0,010 & 0,007 & 0,970 & 0,332 \\
> KIN_KEU & & & & & 0,304 \\
MAN_ENT -> AGR_PAJ- & $-0,013$ & $-0,014$ & 0,013 & 1,029 & \\
\hline > KIN_KEU & & & & &
\end{tabular}

Sumber: Data Penelitian, 2019

Hipotesis biaya politik dalam positive accounting theory (Watts \& Zimmerman, 1986) tidak didukung oleh hasil pengujian hipotesis 1 , nilai $t$ statistik 1,598 lebih rendah dari 1,96 ( $p$ value 0,111 lebih tinggi dari 0,05 ). Teori 
tersebut berargumen bahwa perusahaan besar yang sensitif terhadap aspek politik memililiki kecenderungan untuk menggunakan suatu metode akuntansi tertentu untuk mengurangi laba. Tujuannya mengurangi biaya politik yang ditanggung perusahaan, dalam penelitian ini adalah beban pajak.

Komite audit memiliki tugas utama untuk membantu dewan komisaris untuk memonitor kebijakan yang dibuat manajemen. Tugas komite audit mengacu pada peraturan OJK No.55/POJK.05/2015 terkait dengan penelaahan informasi keuangan yang akan dikeluarkan perusahaan, ketaatan terhadap peraturan perundang-undangan, hal-hal yang berkaitan dengan akuntan, auditor internal, dan eksternal, analisis pelaksanaan manajemen risiko, serta menjaga kerahasiaan dokumen perusahaan. Seluruh tugas tersebut merupakan fungsi pengawasan, sementara itu keputusan mengenai strategi perpajakan perusahaan berada ditangan manajer. Besarnya dana kas yang keluar membuat perusahaan sangat teliti dalam membuat kebijakan terkait perpajakan. Strategi yang diambil merupakan wewenang manajemen, termasuk mengenai keputusan untuk taat terhadap peraturan perpajakan atau sebaliknya melakukan tindakan mengurangi beban pajak. Komite audit hanya bertugas sebagai pengawas, sehingga tidak memiliki hubungan terkait tindakan agresivitas pajak perusahaan.

Temuan ini sejalan dengan penelitian (Okrayanti, Utomo, \& Nuraina, 2017) (Yuniarwati, Ardana, Dewi, \& Lin, 2017) dan (Saputra, 2018) bahwa komite audit tidak berpengaruh terhadap agresivitas pajak. Tindakan agresivitas pajak dapat diminimalisasi, bukan dari jumlah komite audit melainkan dari kinerja yang dilakukan sebagai pengawas perusahaan.

Hasil penelitian ini telah gagal mendukung agency theory (Jensen \& Meckling, 1976) melalui pengujian hipotesis 2, nilai t statistik 1,307 lebih rendah dari 1,96 ( $p$ value 0,192 lebih tinggi dari 0,05). Tindakan penghindaran pajak bukan merupakan strategi CEO untuk mempertahankan posisinya di perusahaan. Tujuan perusahaan melakukan tindakan agresivitas pajak hanya untuk mengurangi beban pajak yang dinilai banyak menggerus laba. Aturan perpajakan Indonesia khususnya pajak penghasilan badan mewajibkan perusahaan membayar 25\% dari laba sebelum pajak. Artinya perusahaan harus menyisihkan hampir seperempat laba yang dihasilkan untuk membayar pajak, angka yang cukup memberatkan bagi perusahaan. Kondisi ini menjadi pemicu manajer untuk teliti dan akurat dalam membuat perencanaan perpajakan perusahaannya.

Hal menarik ketika melihat statistik deskriptif proxy tenur manajerial menunjukkan rata-rata CEO menjabat di suatu perusahaan adalah 12,4 tahun, terlama hingga 47 tahun. Data ini memberikan informasi bahwa karakteristik perusahaan di Indonesia tidak hanya merupakan perusahaan keluarga, selain itu juga masa jabatan CEO yang panjang. Fakta ini memberikan gambaran bahwa CEO dengan masa jabatan yang lama tidak melakukan aktivitas managerial entrenchment, melainkan karena mereka adalah pendiri perusahaan sekaligus pemilik saham mayoritas atau memiliki afiliasi dengan pemilik perusahaan. Alasan untuk tetap menjabat sebagai CEO adalah agar lebih leluasa mengendalikan arah perusahaan dalam lingkungan bisnis atau belum bisa mempercayakan perusahaan dikelola oleh orang lain. 
Penelitian ini memberikan hasil yang berbeda dari beberapa penelitian sebelumnya bahwa managerial entrenchment tidak berpengaruh terhadap agresivitas pajak. Temuan ini bertolak belakang dengan penelitian (Fudenberg \& Tirole, 1995) yang dalam penelitiannya menyimpulkan bahwa manajer yang berusaha untuk memperpanjang masa kerjanya di perusahaan memiliki kecenderungan untuk melakukan tindakan income smoothing. Selain itu, hasil ini juga menunjukkan hasil berbeda dengan (Brochet \& Gao, 2004) bahwa ketika kondisi managerial entrenchment yang rendah terjadi peningkatan manajemen laba yang dilakukan manajer. Hasil ini juga kontradiktif dengan temuan(Meo, Manuel, Lara, \& Surroca, 2017) ketika terdapat insentif, CEO yang melakukan entrenchment akan lebih rendah melakukan manipulasi laba melalui aktivitas manipulasi akrual atau real untuk mencapai laporan keuangan yang diinginkan. Hasil pengujian hipotesis 3 tidak dapat membuktikan agency theory (Jensen \& Meckling, 1976) yang menjelaskan bahwa manajer dapat membuat keputusan yang menguntungkannya, namun merugikan pemilik perusahaan. Nilai $t$ statistik 1,447 lebih rendah dari 1,96 ( $p$ value 0,148 lebih tinggi dari 0,05 ). Tugas utama komite audit adalah membantu dewan komisaris dalam mengawasi perusahaan. Efektivitas komite audit bisa saja meningkatkan corporate governance, namun tidak mempengaruhi kinerja keuangan perusahaan.

Tugas utama komite audit adalah melakukan fungsi pengawasan. Ketika komite audit melakukan fungsinya dengan efektif, maka perusahaan berjalan sesuai koridornya. Hasil yang diperoleh antara lain informasi keuangan yang dipublikasikan berkualitas karena melalui analisis komite audit, perusahaan taat pada aturan perundang-undangan yang berlaku, pemeriksaan berkala melalui auditor internal maupun eksternal, serta aktivitas manajemen risiko berjalan baik. Hal ini bisa dikatakan berdampak pada fungsi pengawasan, sementara itu kinerja keuangan lebih ditentukan oleh strategi manajemen. Para manajer inilah yang merencanakan dan mengimplementasikan strategi untuk mencapai kinerja yang diharapkan. Strategi tersebut mencakup semua aspek bisnis seperti strategi pemasaran yang efektif, pengelolaan keuangan yang rapi, akuntabel, dan transparan, proses produksi yang efisien, serta pengelolaan sumber daya manusia dengan cara profesional. Ketika seluruh aspek tersebut berjalan, maka peningkatan kinerja keuangan dapat tercapai.

Hasil penelitian ini sejalan dengan (Widyati, 2013) yang menyatakan komite audit tidak memiliki pengaruh terhadap kinerja keuangan. Jumlah komite audit bukan merupakan ukuran yang tepat dalam menilai efektifitas komite audit dalam mengawasi kinerja manajemen.

Argumentasi agency theory (Jensen \& Meckling, 1976) berhasil dibuktikan melaui hasil pengujian hipotesis 4 , nilai $\mathrm{t}$ statistik 3,835 lebih tinggi dari 1,96 ( $p$ value 0,000 lebih rendah dari 0,05$)$. Managerial entrenchment yang dicerminkan oleh masa kerja CEO yang lama membuat permintaan perusahaan untuk monitoring CEOnya berkurang. Hal ini disebabkan karena ketelitian penilaian pemilik terhadap kemampuan CEOnya meningkat (Dikolli et al., 2014). Terdapat dua asumsi untuk memperkuat prediksi ini, pertama perusahaan melakukan monitoring terhadap CEO untuk mengumpulkan informasi tentang kemampuan CEO meningkatkan nilai perusahaan. Ketidakpastian ini dijawab oleh masa kerja (tenure) CEO, permintaan pemilik atas informasi ini berkurang. Kedua, 
monitoring menjadi biaya yang besar bagi pemilik perusahaan. Biaya monitoring yang besar membuat intensitas monitoring terhadap kemampuan CEO berkurang.

Akibat berkurangnya pengawasan, penguasaan sumber daya perusahaan oleh manajer semakin bertambah. Manajer semakin leluasa untuk menggunakan sumber daya tersebut dalam keputusan investasi bukan pembagian dividen (free cash flow). Ada kalanya manajer menggunakan sumber daya perusahaan pada investasi yang tidak profitable atau pembelian barang modal (cost of capital). Kedua pilihan tersebut dapat berdampak pada penurunan kinerja keuangan, kerugian akibat pilihan investasi yang tidak menguntungkan dan pembelian barang modal yang membebani laporan keuangan. Temuan penelitian ini sejalan dengan (Dikolli et al., 2014) yang menyimpulkan bahwa masa kerja CEO yang lama berpengaruh negatif terhadap kinerja perusahaan. Lamanya masa kerja CEO membuat berkurangnya permintaan monitoring dan penilaian (pemecatan) berdasakan kinerja, hal ini karena lemahnya mekanisime corporate governance yang pada akhirnya berimbas pada penurunan kinerja perusahaan. Penelitian lain yang sejalan dengan hasil penelitian ini adalah (Mohamed et al., 2015) yang menyimpulkan bahwa masa keja CEO yang lama berakibat pada menurunnya nilai perusahaan. CEO dengan tenur yang lama mengindikasikan lemahnya sensitifitas turnover berbasis kinerja. CEO dengan kinerja yang kurang maksimal dapat berimbas pada penurunan nilai dan kinerja perusahaan.

Hasil penelitian ini mendukung agency theory (Jensen \& Meckling, 1976) dengan diterimanya hipotesis 5 yang menyatakan bahwa manajer tidak selalu bertindak untuk kepentingan prinsipal. Hal ini dibuktikan oleh nilai $\mathrm{t}$ statistik 3,403 lebih tinggi dari 1,96 ( $p$ value 0,001 lebih rendah dari 0,05). Manajer dapat membuat keputusan oportunistik untuk kepentingan pribadi namun merugikan pemilik saham. Tindakan oportunistik manajer yang dalam penelitian ini adalah agresivitas pajak berakibat pada penurunan kinerja keuangan perusahaan. Semakin tinggi tindakan agresivitas pajak maka semakin rendah kinerja keuangan perusahaan.

Agresivitas pajak dapat menutupi tindakan rent extraction manajer (Desai \& Dharmapala, 2006) yaitu tindakan manajer yang tidak memberikan value bagi shareholders seperti manipulasi laporan keuangan, mengambil alih aset perusahaan untuk kepentingan pribadi, dan bertransaksi dengan pihak yang memiliki hubungan istimewa (Chen et al., 2010). Laporan keuangan yang tidak relevan, aset yang tidak maksimal dalam menghasilkan return, dan kerugian akibat bertransaksi dengan pihak tertentu dapat merugikan perusahaan yang berakibat pada penurunan kinerja keuangan.

Hasil penelitian ini sejalan dengan temuan (Kartikaningdyah \& Putri, 2017) bahwa agresivitas pajak berpengaruh signifikan negatif terhadap kinerja keuangan. Agresivitas pajak membuka peluang bagi manajer untuk melakukan tindakan oportunistik yang mengakibatkan penurunan transparansi keuangan. Imbasnya adalah terjadi penurunan kinerja keuangan perusahaan. Temuan yang sama ditunjukkan oleh (Hanlon \& Slemrod, 2009). Berita mengenai tindakan agresivitas pajak perusahaan dimaknai negatif oleh investor, mereka menilai hal tersebut adalah budaya perusahaan untuk melawan otoritas pajak dan sebagai tanda adanya insiders yang ingin mencari keuntungan. Relevansi informasi yang 
terkandung dalam laporan keuangan mulai diragukan investor sehingga memunculkan reaksi negatif yang berdampak pada menurunnya harga saham perusahaan. (Katz, Khan, \& Schmidt, 2015) membuktikan bahwa tax avoidance berpengaruh negatif terhadap kinerja perusahaan di masa depan. Hasil ini disebabkan oleh rendahnya aset operasional, liabilitas operasi, dan efisiensi.

Tabel 5. Total Effect

\begin{tabular}{llllll}
\hline & $\begin{array}{l}\text { Original } \\
\text { Sample } \\
(\mathrm{O})\end{array}$ & $\begin{array}{l}\text { Sample } \\
\text { Mean } \\
(\mathrm{M})\end{array}$ & $\begin{array}{l}\text { Standard } \\
\text { Deviation } \\
(\mathrm{STDEV})\end{array}$ & $\begin{array}{l}\mathrm{T} \text { Statistics } \\
(|\mathrm{O} / \mathrm{STDEV}|)\end{array}$ & $\begin{array}{l}\mathrm{P} \\
\text { Values }\end{array}$ \\
\hline KOM_AUD -> AGR_PAJ & $-0,042$ & $-0,049$ & 0,027 & 1,598 & 0,111 \\
MAN_ENT -> AGR_PAJ & 0,077 & 0,077 & 0,059 & 1,307 & 0,192 \\
KOM_AUD & $-0,047$ & $-0,044$ & 0,037 & 1,271 & 0,204 \\
KIN_KEU & $-0,209$ & $-0,213$ & 0,053 & 3,945 & 0,000 \\
MAN_ENT -> KIN_KEU & $-0,209$ & 0,001 \\
AGR_PAJ -> KIN_KEU & $-0,170$ & $-0,197$ & 0,050 & 3,403 & \\
\hline
\end{tabular}

Sumber: Data Penelitian, 2019

Positive accounting theory (Watts \& Zimmerman, 1986) tidak didukung oleh hasil pengujian hipotesis 6 . Berdasarkan total effect, komite audit tidak berpengaruh terhadap agresivitas pajak dibuktikan oleh nilai $t$ statistik 1,598 lebih rendah dari 1,96 ( $p$ value 0,111 lebih tinggi dari 0,05 ). Hasil yang sama ditunjukkan oleh komite audit terhadap kinerja keuangan yang tidak berpengaruh melalui nilai $\mathrm{t}$ statistik 1,271 lebih rendah dari 1,96 ( $p$ value 0,204 lebih tinggi dari 0,05). Nilai tersebut berarti hubungan komite audit terhadap kinerja keuangan melalui agresivitas pajak bersifat mediasi penuh (fully mediating).

Komite audit bukan merupakan pihak yang menentukan kebijakan perpajakan perusahaan. Ranah tersebut adalah milik manajer sebagai decision maker. Manajer memiliki kekuasaan untuk menentukan kebijakan perusahaan termasuk berbagai hal yang terkait dengan perpajakan, komite audit bertindak sebatas pada pengawasan agar kebijakan tersebut tidak keluar dari koridornya. Peraturan OJK Nomor 55/POJK.04/2015 menjelaskan tentang tugas dan tanggung jawab komite audit, antara lain melakukan penelaahan atas informasi keuangan yang akan dikeluarkan perusahaan, penelaahan atas ketaatan terhadap peraturan perundang-undangan terkait kegiatan perusahaan, memberikan rekomendasi kepada dewan komisaris mengenai penunjukan akuntan, penelahaahan atas pemeriksaan auditor internal dan tindak lanjutnya oleh direksi, penelaahan pelaksanaan manajemen risiko dan sebagainya. Keseluruhan tugas ini adalah fungsi pengawasan bukan pembuat keputusan.

Kinerja keuangan lebih ditentukan oleh strategi dan eksekusi yang dilakukan manajer. Para manajer inilah yang bertindak sebagai pembuat keputusan atas arah bisnis perusahaan. Strategi yang tepat dengan eksekusi yang sempurna akan menghasilkan peningkatan kinerja keuangan, sebaliknya strategi dan eksekusi yang buruk menghasilkan penurunan kinerja keuangan. Komite audit memiliki peran sebagai pengawas bukan pembuat keputusan sehingga tidak memiliki pengaruh terhadap tinggi rendahnya kinerja keuangan.

Argumentasi agency theory (Jensen \& Meckling, 1976) tidak dapat dibuktikan melalui hasil pengujian hipotesis 7 . Tabel total effect menunjukkan 
bahwa managerial entrenchment tidak berpengaruh terhadap agresivitas pajak dibuktikan oleh nilai $\mathrm{t}$ statistik 1,307 lebih rendah dari 1,96 ( $p$ value 0,192 lebih tinggi dari 0,05). Sementara itu, managerial entrenchment terhadap kinerja keuangan memiliki pengaruh signifikan ditunjukkan oleh nilai $t$ statistik 3,945 lebih rendah dari 1,96 ( $p$ value 0,000 lebih rendah dari 0,05 ). Nilai tersebut berarti hubungan managerial entrenchment terhadap kinerja keuangan melalui agresivitas pajak bersifat mediasi semu (quasi mediating).

Agresivitas pajak bukan merupakan variabel yang dapat menjembatani hubungan managerial entrenchment dan kinerja keuangan. Managerial entrenchment memiliki hubungan langsung dengan kinerja keuangan, begitu juga dengan agresivitas pajak yang memiliki hubungan langsung dengan kinerja keuangan. Managerial entrenchment memperpanjang masa kerja manajer (CEO) diperusahaan. Permintaan perusahaan untuk mengawasi manajernya menjadi berkurang akibat lamanya masa kerja manajer. Ketika aktivitas monitoring berkurang, manajer semakin menguasai sumber daya perusahaan dan lebih leluasa dalam menggunakannya. Ada saatnya manajer menggunakan sumber daya perusahaan pada investasi yang tidak menguntungkan sehingga terjadi kerugian dan pada pembelian barang modal yang membebani laporan keuangan. Kedua pilihan tersebut dapat berimbas pada penurunan kinerja keuangan.

\section{SIMPULAN}

Komite audit tidak berpengaruh terhadap agresivitas pajak. Komite audit bertugas untuk melakukan pengawasan dan tidak memiliki kewenangan dalam memutuskan kebijakan perpajakan perusahaan.

Managerial entrenchment tidak berpengaruh terhadap agresivitas pajak. Manajer (CEO) tidak menggunakan agresivitas pajak sebagai strategi mempertahankan posisinya di perusahaan, para CEO dengan masa kerja yang lama merupakan pendiri perusahaan atau memiliki hubungan afiliasi dengan pemilik.

Komite audit tidak berpengaruh terhadap kinerja keuangan. Kinerja keuangan lebih ditentukan oleh strategi dan implementasi dalam pengelolaan perusahaan terkait keuangan, pemasaran, produksi, dan sumber daya manusia. Tugas ini diemban oleh manajer sebagai pembuat keputusan, sementara komite audit bertugas untuk mengawasi kebijakan perusahaan agar tetap berada dalam koridornya.

Managerial entrenchment berpengaruh signifikan negatif terhadap kinerja keuangan. Masa kerja manajer (CEO) yang lama mengurangi permintaan monitoring dan penilaian (pemberhentian kerja) berdasarkan kinerja. Hal ini membuat penguasaan sumber daya perusahaan oleh manajer semakin besar. Sumber daya tersebut dapat digunakan manajer pada investasi yang tidak profitable atau pembelian barang modal yang berakibat pada penurunan kinerja keuangan.

Agresivitas pajak berpengaruh signifikan negatif terhadap kinerja keuangan. Tindakan agresivitas pajak memberikan kerugian bagi perusahaan, seperti sanksi dari otoritas pajak, laporan keuangan yang tidak transparan, dan rent extraction yang berakibat pada menurunnya kinerja keuangan perusahaan. 
Komite audit tidak berpengaruh terhadap kinerja keuangan melalui agresivitas pajak. Kinerja keuangan lebih banyak ditentukan oleh strategi dan implementasi manajer, komite audit hanya berperan sebagai pengawas atas kebijakan yang dibuat manajer. Bahkan ketika terjadi agresivitas pajak, komite audit tidak memiliki pengaruh yang kuat terhadap kinerja keuangan perusahaan.

Managerial entrenchment tidak memiliki pengaruh terhadap kinerja keuangan melalui agresivitas pajak. Agresivitas pajak bukan merupakan strategi manajer (CEO) untuk mempertahankan posisinya di perusahaan, sehingga tidak dapat mengurangi kinerja keuangan. Managerial entrenchment dan agresivitas pajak memiliki pengaruh langsung terhadap kinerja keuangan perusahaan.

Hasil analisis data menunjukkan managerial entrenchment berpengaruh negatif terhadap kinerja keuangan. Ketika manajer (CEO) melakukan strategi entrenchment yang dapat memperpanjang masa kerjanya di perusahaan akan berdampak pada penurunan kinerja keuangan. Temuan ini memberikan hasil berbeda dari teori yang ada serta penelitian terdahulu, sehingga memunculkan keraguan atas hasil ini. Umumnya CEO dengan masa kerja (tenur) yang lama akan memiliki pemahaman dan insting yang mendalam terhadap industri dimana perusahaannya berkecimpung serta memiliki jaringan luas yang memudahkannya untuk mendapat berbagai akses ke sumber daya yang hanya dimiliki beberapa golongan tertentu. Berbagai keunggulan tersebut sangat membantu dalam mengeksekusi strategi yang telah direncanakan untuk mencapai tujuan perusahaan termasuk meningkatkan kinerja keuangan.

Penelitian selanjutnya dapat mempertimbangkan untuk menggunakan proxy lain untuk setiap variabel. Seperti komite audit menggunakan jumlah anggota dengan keahlian akuntansi dan keuangan serta latar belakang pendidikan, managerial entrenchment dengan kepemilikan manajerial. Agresivitas pajak dengan cash effective tax rates, book tax difference, discreationary permanent BTDs (DTAX), kinerja keuangan dapat menggunakan net profit margin atau rasio lain seperti liquiditas, solvabilitas, dan aktivitas.

Berbagai skema agresivitas pajak yang umum digunakan seperti transfer pricing, controlled foreign corporation (CFC), conduit company, dan thin capitalization dalam jangka pendek terlihat menghemat kas perusahaan, namun dampak jangka panjang yang ditimbulkan sangat fatal seperti penurunan kinerja keuangan, turunnya harga saham, sanksi dari otoritas pajak sampai dengan rusaknya nama baik perusahaan. Manajemen perusahaan sebaiknya menghindari strategi ini demi kepentingan perusahaan dan negara.

\section{REFERENSI}

Allen, M. P. (1981). Managerial Power and Tenure in The Large Corporation. Social Forces, 60(2), 482-494.

Balakrishnan, K., Blouin, J., \& Guay, W. (2011). Does Tax Aggressiveness Reduce Financial Reporting Transparency? Pennsylvania.

Blaylock, B. S. (2016). Is Tax Avoidance Associated with Economically Significant Rent Extraction among U . S . Firms ?*. Contemporery Accounting Research, 33(3), 1013-1043. https://doi.org/10.1111/1911-3846.12174 
Brochet, F., \& Gao, Z. (2004). Managerial Entrenchment and Earnings Smoothing. New York.

Chen, S., Chen, X., \& Shevlin, T. (2010). Are family firms more tax aggressive than non-family firms? *. Journal of Financial Economics, 91(1), 414461.

Desai, M. A., \& Dharmapala, D. (2006). Corporate Tax Avoidance and HighPowered Incentives. Journal of Financial Economics, 79, 145-179.

Dewi, N. N. K., \& Jati, I. K. (2014). Pengaruh Karakter Eksekutif, Karakteristik Perusahaan, dan Dimensi Tata Kelola Perusahaan Yang Baik Pada Tax Avoidance Di Bursa Efek Indonesia. E-Jurnal Akuntansi Universitas Udayana, 6(2), 249-260.

Dikolli, S. S., Mayew, W. J., \& Nanda, D. (2014). CEO tenure and the performance-turnover relation. Review of Accounting Studies, 19(1), 281-327. https:// doi.org/10.1007/s11142-013-9247-6

Dyreng, S., Hanlon, M., \& Maydew, E. L. (2018). When Does Tax Avoidance Result in Tax Uncertainty? When Does Tax Avoidance Result in Tax Uncertainty? The Accounting Review, 94(2), 179-203.

Edogbanya, A., \& Kamardin, H. (2006). Company reporting transparency and firm performance in nigeria. Asia Pacific of Advanced Business and Social Studies, 2(2), 346-356.

Frank, M. M., Lynch, L. J., \& Rego, S. O. (2009). Tax Reporting Aggressiveness and Its Relation to Aggressive Financial Reporting. The Accounting Review, 84(2), 467-496.

Fudenberg, D., \& Tirole, J. (1995). A Theory of Income and Dividend Smoothing Based on Incumbency Rents. Journal of Political Economy, 103(1), 7593.

Gaaya, S., Lakhal, N., \& Lakhal, F. (2017). Does Family Ownership Reduce Corporate Tax Avoidance? The Moderating Effect of Audit Quality Avoidance. Managerial Auditing Journal, 32(7), 731-744. https:// doi.org/10.1108/MAJ-02-2017-1530

Gantino, R. (2016). Pengaruh Corporate Social Responsibility Terhadap Kinerja Keuangan Perusahaan Manufaktur yang Terdaftar di Bursa Efek Indonesia periode 2008-. Jurnal Dinamika Akuntansi Dan Bisnis, 3(2), 19-32.

Hair, J. F., Hult, G. T. M., Ringle, C. M., \& Sarstedt, M. (2014). A Primer on Partial Least Square Structural Equation Modeling (PLS-SEM). Los Angeles: SAGE Publications, Inc.

Handajani, L., Subroto, B., Sutrisno, T., \& Saraswati., E. (2014). Pengungkapan tanggung jawab sosial perusahaan: determinan dan konsekuensi. Proceedings Simposium Nasional Akuntansi XVII. Lombok.

Hanlon, M., \& Slemrod, J. (2009). What Does Tax Aggressiveness Signal? Evidence From Stock Price Reactions to News About Tax Shelter Involvement. Journal of Public Economic, 93, 126-141.

Hapsoro, D. (2008). Pengaruh Mekanisme Corporate Governance Terhadap Kinerja Perusahaan: Studi Empiris di Pasar Modal Indonesia. Jurnal Akuntansi Dan Manajemen, 19(3), 155-172. 
Jensen, C. M., \& Meckling, W. H. (1976). Theory of The Firm: Managerial Behavior, Agency Costs and Ownership Structure. Journal of Financial Economics, 3(4), 305-360.

Kartikaningdyah, E., \& Putri, R. N. (2017). Pengaruh Tax Avoidance dan Board Diversity terhadap Kinerja Perusahaan dalam Perspektif Corporate Governance. Journal of Applied Accounting and Taxation, 2(2), 114-122.

Katz, S., Khan, U., \& Schmidt, A. P. (2015). Tax Avoidance and DuPont Measures of Future Performance. In Columbia Business School Research Paper.

Komite Nasional Kebijakan Governance. Corporate Governance. , (2006).

Lanis, R., \& Richardson, G. (2011). J . Account . Public Policy The effect of board of director composition on corporate tax aggressiveness. Journal of Accounting and Public Policy, 30(1), 50-70. https://doi.org/10.1016/j.jaccpubpol.2010.09.003

Manik, T. (2011). Analisis Pengaruh Kepemilikan Manajemen, Komisaris Independen, Komite Audit, Umur Perusahaan Terhadap Kinerja Keuangan. Journal of Entrepreneurship, Management and Industry, 2(2), 25-36.

Mardiasmo. (2011). Perpajakan Edisi Revisi. Yogyakarta: Andi Offset.

Meo, D. F., Manuel, J., Lara, G., \& Surroca, J. A. (2017). Managerial Entrenchment and Earnings Management. Journal of Accounting and Public Policy, 36(5), 399-414. https://doi.org/10.1016/j.jaccpubpol.2017.07.003

Midiastuty, P. P., Suranta, E., \& Ramdhan, P. M. (2017). Pengaruh Kepemilikan Terkonsentrasi Dan Corporate Governance Terhadap Agresivitas Pajak. Proceedings Simposium Nasional Akuntansi XX. Jember, 1-26.

Mohamed, E. Ben, Jarboui, S., Baccar, A., \& Bouri, A. (2015). On The Effect of CEOs Personal Characteristics in Transport Firm Value? A Stochastic Frontier Model. Case Studies on Transport Policy, 3(2), 176181. https:// doi.org/10.1016/j.cstp.2015.01.001

Okrayanti, T. Y., Utomo, S. W., \& Nuraina, E. (2017). Pengaruh Karakteristik Perusahaan Dan Corporate Governance Terhadap Tax Avoidance. Forum Ilmiah Pendidikan Akutansi Universitas PGRI Madiun, 5(1), 804817.

Pradana, A. B., \& Ardiyanto, M. D. (2017). Pengaruh Karakteristik Pengawasan Dewan Komisaris Terhadap Agresivitas Pajak Perusahaan. 6(4), 1-9.

Saputra, A. D. (2018). Pengaruh Insentif Eksekutif, Corporate Risk, Corporate Governance, Dan Konservatisme Akuntansi Terhadap Tax Avoidance. Universitas Islam Indonesia.

Sari, S. R., Astuti, T. P., Suseno, A. E., \& Rahmawati. (2017). Kepemilikan Keluarga dan Tindakan Pajak Agresif. Proceedings Simposium Nasional Akuntansi XX. Jember.

Shleifer, A., \& Vishny, R. W. (1988). Management Entrenchment: The Case of Manager-Specific Investments. Journal of Financial Economics, 25, 123-139. https:/ / doi.org/10.1016/0304-405X(88)90048-7

Sudiyatno, B., \& Puspitasari, E. (2010). Tobin's q dan Altman Z-Score Sebagai Indikator Pengukuran Kinerja Perusahaan. Kajian Akuntansi, 2(1), 921. 
Sugiyono. (2012). Metode Penelitian Bisnis (Pendekatan Kuantitatif, Kualitatif, dan $R \mathcal{E D})$. Bandung: Alfabeta.

Surroca, J., \& Tribo, J. A. (2008). Managerial Entrenchment and Corporate Social Performance. 35(July), 748-789. https://doi.org/10.1111/j.14685957.2008.02090.x

Utami, R. P., \& Syafiqurrahman, M. (2017). Pengaruh Organ-Organ Pendukung Good Corporate Governance Terhadap Tax Avoidance. Jurnal InFestasi, 13(2), 380-389.

Walsh, J. P., \& Seward, J. K. (1990). On The Efficiency of Internal and External Corporate Control Mechanisms. Academy of Management Review, 15(3), 421-458.

Watts, R. L., \& Zimmerman, J. L. (1986). Positive Accounting Theory. Prentice Hall International Inc.

Widyati, M. F. (2013). Pengaruh Dewan Direksi, Komisaris Independen, Komite Audit, Kepemilikan Manajerial, dan Kepemilikan Institusional Terhadap Kinerja Keuangan. Jurnal Ilmu Manajemen, 1(1), 234-249.

Wulansari, N., \& Dewi, H. R. (2017). Pengaruh Kepemilikan Institusional, Proporsi Dewan Komisaris Independen, Komite Audit, Konservatisme Akuntansi, Pertumbuhan Penjualan Dan Leverage Terhadap Penghindaran Pajak. Proceedings Simposium Nasional Akuntansi XX. Jember, 1-27.

www.detik.com. (2014). Kejagung PT. Asian Agri Lunasi Denda Rp 25 Triliun. Retrieved from 2014 website: https://www.detik.com/news/berita/d-2698916/kejagung-ptasian-agri-lunasi-denda-rp-25-triliun

www.ortax.org. (2007). Inilah Delapan Tersangka Kasus Pajak Asian Agri. Retrieved from 2007 website: https:/ / ortax.org/ ortax $/$ mod=berita\&page $=$ show $\&$ id $=559 \& q=\& q$ $=\& \mathrm{hlm}=846 \% 0 \mathrm{~A}$

Yuniarwati, Ardana, I. C., Dewi, S. P., \& Lin, C. (2017). Factors That Influence Tax Avoidance in Indonesia Stock Exchange. Chinese Business Review, 16(10), 510-517. https://doi.org/10.17265/1537-1506/2017.10.005

Zheng, T., Jiang, W., Zhao, P., Jiang, J., \& Wang, N. (2019). Will the Audit Committee Affects Tax Aggressiveness? Proceedings of The Twelfth International Conference on Management Science and Engineering Management, 1313-1326. https:/ / doi.org/10.1007/978-3-319-93351-1 